\title{
Scamander: FromTrojan Wartoend of Antiquity It's Mythology and Iconography
}

\author{
Reyhan Korpe \\ Canakkale Onsekiz Mart University \\ Faculty of Arts and SciencesDepartment of History, \\ TerziogluCampus, 17100 Canakkale, Turkey \\ E-mail: rkorpe@comu.edu.tr
}

\begin{abstract}
Scamander, the largest river of the Troad, flows from Mount Ida past Troy and into the Hellespont. Large number of ancient settlements (prehistoric, classical, Byzantine) are located near its banks. Scanmander was also personified as the River-God of the region. According to Homer, Scamander attacks Achilles to help the Trojans. Since he was an important figure in the topography and mythology of the Trojan War, Scamander was often depicted in ancient art and on coins. This study focuses on the image of Scamander both in ancient mythology and art.
\end{abstract}

Keywords: Scamander, Trojan War, Antiquity

DOI: $10.7176 / J S T R / 5-2-40$

\section{Troia Savaşlarından Antik Dönemin Sonuna Kadar Skamandros Irmağı: Mitolojisi ve İkonografisi}

Özet

Troas'ın en büyük akarsuyu, bir kente de ismini vermiş olan Skamandros’tur. İda Dağından çıkanırmak Çanakkale Boğazı'nın ağzından denize dökülür. Nehir havzasında İda Dağından, Çanakkale Boğazına döküldüğü yaklaşık $80 \mathrm{~km}$. mesafe boyunca prehistorik dönemden, Bizans’a kadar çok sayıda antik yerleşim bulunmaktadır. Skamandros başta Homeros'un İliada destanı olmak üzere olmak üzere, antik mitolojide en fazla adı geçen irmaklardan biridir. Aynı zamanda bir ırmak tanrısı olan Skamandros'unTroas bölgesi mitolojisinde önemli bir yeri vardır. Homeros, Skamandros'un Troia savaşlarında Akhilleus'a karşı çarpıştığını söyler. Antik çağda Skamandros ırmak tanrısı olarak çok sayıda heykel ve kabartmanın yanı sıra sikkeler üzerinde de tasvir edilmişsir. Makalemizde Skamandros'un mitolojideki yerinin yanı sıra ikonografik incelemesi yapılmıştır.

\section{Giris}

Günümüzde Çanakkale il sınırları içinde yer alan bölge Biga Yarımadası olarak da bilinir. Yarımadanın doğu kısımları haricinde kalan bölümü antik çağlarda Troas olarak adlandırılmıştır. Burası kabaca, kuzeyde Gönen Çayı'ndan güneye Edremit Körfezine çekilen bir çizginin batısını kapsamaktadır.

Bölgenin belli başlı akarsuları: kuzeyde Marmara Denizi’ne akan Gönen (Aisepos) ve Kocabaş (Granikos) çayları, Çanakkale Boğazı'na dökülen Umurbey (Praktios), Sarıçay (Rhodios), Dümrek (Simoeis) ve Karamenderes (Skamandros) çayları ile batıda Ege Denizi'ne dökülen Tuzla (Satnioeis) çayıdır. Kaz Dağları'ndan çıkan bu ırmakların oluşturduğu alüvyon ovalar hem dağlar arasındaki vadileri, hem de kıyılardaki dağlık alanları çevreler.

Troas'in en büyük akarsuyu, bir kente de ismini vermiş olan Skamandros'tur. (RESİM 1) Bu rrmak, iç Troas'daki kaynaklarından çıktıktan sonra önce batıya, sonra Ezine ovasından kuzeye doğru kıvrılarak, Çanakkale Boğazı'nın ağzından denize dökülür. Skamandros'un çıktıktan sonra gittikçe genişleyen vadisi yukarı, orta ve aşağı olmak üzere üç parçaya ayrılır. Yukarı Skamandros havzası, ırmağın ana kaynağından itibaren Bayramiç ovasını, Orta Skamandros Ezine ovasını, Aşağı Skamandros ise Pınarbaşı'ndan itibaren Kumkale ovasını oluşturur. Nehir boyunca, nehrin çıktığı İda Dağı eteklerinden, Çanakkale Boğazına döküldüğ̈̈ yaklaşık $80 \mathrm{~km}$. mesafe boyunca prehistorik dönemden, Bizans'a kadar çok sayıda antik 
yerleşim bulunmaktadır. (RESİM 2) Çanakkale Boğazından, İda Dağına kadar geniş bir coğrafyayı birbirine bağlayan bu akarsu bölgenin ekonomik ve sosyokültürel hayatında önemli bir rol oynamaktadır. Tarih boyunca Skamandros ırmağı kıyısını takip eden yollar iç Troas ile kıyı arasında ticaret ve iletişimi sağladığı gibi, İda dağından kesilen keresteler nehir boyunca yüzdürülerek taşınmıştır (Körpe 2017; Korfmann 2004; Körpe ve Yavuz 2007).

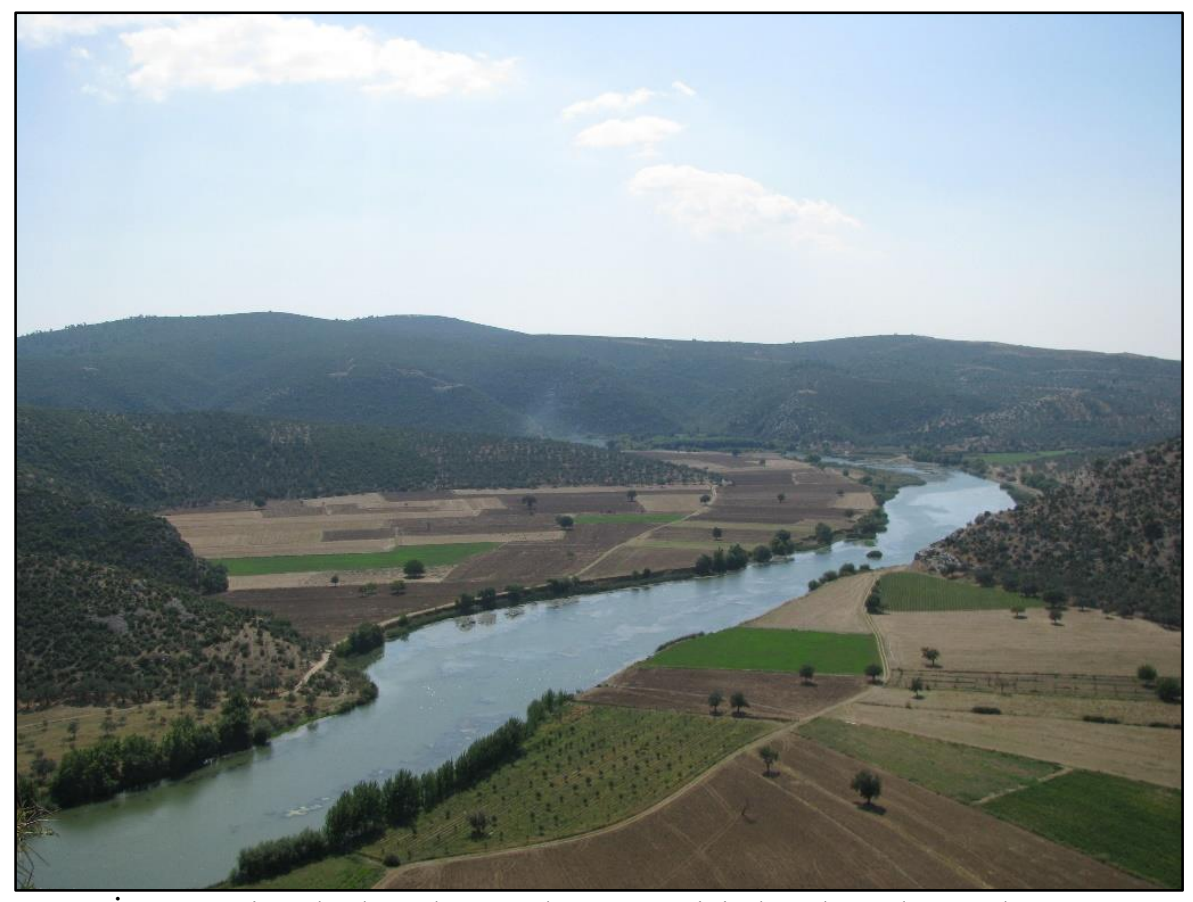

RESIMM 1: Troia yakınlarında, Araplar Boğazı içinden akan Skamandros ırmağ 1

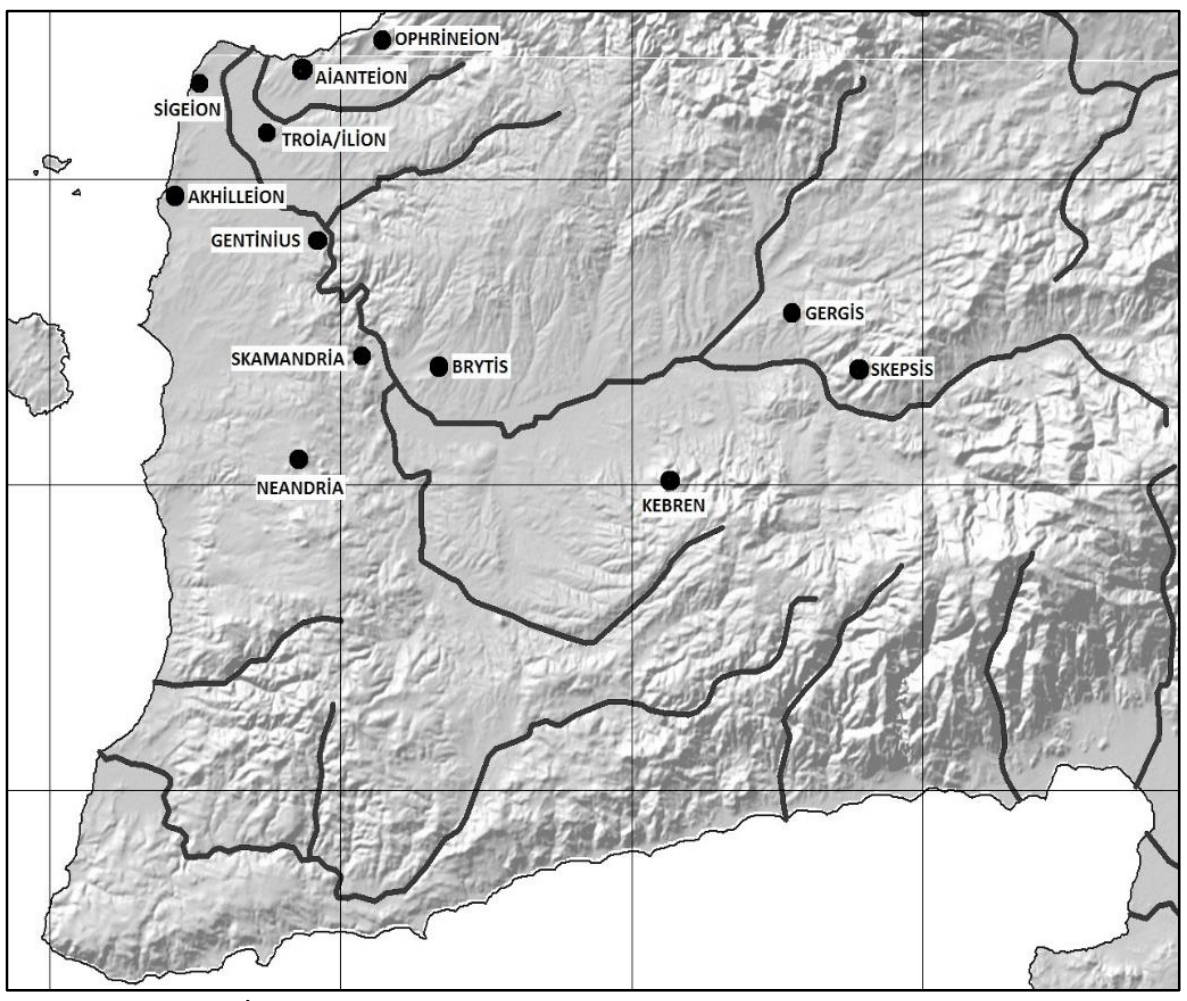

RESIM 2: Skamandros havzası içinde yer alan antik kentler 


\section{Antik Mitolojide Skamandros Irmağı}

Troas bölgesinin en önemli akarsuyu olan Skamandros başta Homeros'un İliada destanı olmak üzere olmak üzere, antik mitolojide en fazla adı geçen ırmaklardan biridir. Homeros'un İliada destanında şair, “Zeus'tan doğma anaforlu Xanthos" diye de bahsettiği Skamandros'un derin girdaplarının olduğunu, ama ovalardan sakin bir şekilde aktığını söylemektedir (Homeros Ill. VI. 4, XX. 73, XXI. 2, XX. 74). Irmağın diğer adı olan Xanthos "kızıl”anlamına gelmektedir. Irmağın içinde yıkanan koyunların tüylerinin kızıllaştığı söylenmektedir. Güzellik tanrıçası Aphrodite'nin de güzellik yarışmasından önce saçlarını Skamandros'ta yıkayarak kızıllaştırdığı anlatılır. Bir başka anlatıma göre ise ırmağın kaynağını kazarak çıkaran Herakles'tir (Erhat 2015).

Aynı zamanda bir ırmak tanrısı olan Skamandros'unTroas bölgesi mitolojisinde önemli bir yeri vardır. Skamandros'unTroas'daki diğer dağ ve nehir tanrıçalarından doğan çocukları Troia kraliyet ailesinin atalarını oluştururlar (Apollodoros, Library 3. 12. 1). Troia kentinin nympheleriSkamandros'un kızlarıdır

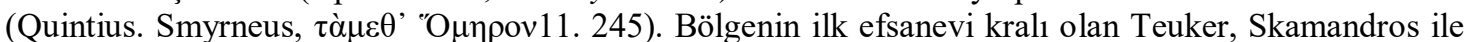
İdaia'nın oğludur (Apollodoros, Library 3. 139; DiodorusSic. 4.75.1). Gene Skamandros'un kızı olan Kallirhoe, Troia kentinin kurucusu Tros ile evlenmiştir. Ayrıca Troia savaşlarında, kentin efsanevi Kralı Priamos'un annesi de Skamandros'un diğer bir kızı Strymo'dur(Dion. Hal. ant.1. 62.9).

Troia mitolojisi ile bu kadar ilişkili olan Skamandros'un adı Troia savaşlarında da sıklıkla geçmektedir. Iliada'da, Skamandros Zeus'un oğlu ve büyük bir tanrı olarak tanımlanır. Troialıların yanında Akhalara karşı mücadele eder Skamandros, Akhilleus'un Troialıları öldürüp cesetlerini ırmağa atması üzerine, sükûnetle akan ırmak birdenbire korkunç bir yere dönüşür. Skamandros kısa bir zaman sonra Akhilleus'un kurbanlarıyla dolar. İçine düşen insanların inlemesi ve akan kanlarıyla rengi kırmızıya döner.

Güzel akan ırmă̆ın siğ yerine gelince,

Zeus'tan doğma anaforlu Xanthos'un siğ yerine,

Akhilleus böldü onları ikiye,

Kimini sürdü ovadan kente doğru,

Akhaların palas pandıras kaçıştıkları yoldan,

Ünlü Hektor kovalamıştı onları bir gün önce,

Bugün o yoldan Troialılar kaçıyordu korku içinde,

Hera önlerine kopkoyu bir bulut sermişti.

Ordunun öbür yarısı da yığılmıştı ırmağın kıyısına,

Derinden akan, gümüş anaforlu ırmağın,

Paldır küldür atılıyordu ırmağın içine,

Derin sular uğulduyor, kıyllar yankllanıyordu,

Bağrışarak yüzüyorlardı o yana bu yana,

Dönüp duruyorlardı anaforla birlikte.

Nasıl havalanırsa bir sürü çekirge,

Ateşten kurtulmak için kaçışırsa ırmağa doğru,

Alev fişkırmıs, onları cayır cayır yakacak,

Sığınak ararlar suda kendilerine,

Akhilleus'un saldırısı altında da tıpkı öyle,

Dolar Xanthos'un derin sulart,

Karma karışık insan, at kalabalı̆̆ıyla.

Zeus'ta doğma yiğit bırakır kargısını kıyıya,

Ilgın ăgaçlarına dayar kargıyı,

Atlar ırmă̆a bir tanrı gibi,

Bir tek kllıcı vardır elinde,

Kötü işler geçirir aklından,

Kılıcını dört bir yana savurur durur,

Yükselir bedenlerden korkunç iniltiler,

Sular boyanır kıpkızl kana.(Homeros, Il. XXI. 1-33.)

Akhilleus Troialıları ırmağın içinde katlederken aynı zamanda bunca kurban vermelerine rağmen, ırmağın kendilerini koruyamadığını da haykırmaktadır

Güzel akan, ak anaforlu trmak ta koruyamaz sizi,

Boşuna kurban ediyorsunuz ona bir sürü boğayl,

Tek tırnaklı atları diri diri atıyorsunuz akıntısina,(Homeros İl. XXI, 130)

351 | P a g e

www.iiste.org 
Akhilleus'un bu son sözleri özellikle Skamandros'u etkilemiş olmalı ki, ırmak hem Akhilleus'un Troialılara yaptığı eziyete, hem de kendisini böyle aşağıllamasına öfkelenir.

Akhilleus iște böyle dedi,

Çoğaldı öfke ırmağın yüreğinde,

Gönlünde düşündü taşındı trmak,

Nastl son versindi Akhilleus'un bu işine,

Troialalıların başından belayı nasıl kovsundu.(Homeros, Ill. XXI, 135.)

Akhilleus, Troialıları ve ona yardıma gelen müttefikleri teker teker öldürürken sonunda Skamandros dayanamadı ve Akhilleus'tan hiç olmazsa bu işi kendisinden uzakta yapmasını, zira ırmak içindeki ölülerin, akışına mani olduğunu söyledi.

Derin anaforlu trmak, benzetip sesini insan sesine,

Derin anaforlarin altında öfkeyle dile gelmeseydi,

Hızlı Akhilleus daha bir sürü Paionialıyı öldürürdü:

"Hey Akhilleus, tekmil insanlardan üstünsün güçte,

Kötü işlerde de geçersin hepsini,

Bütün tanrllar yardım ederler sana.

Bütün Troialıları öldürmen için Kronosoğlu izin vermişse,

Bu korkunç işleri benden uzak yap bari,

Sür onlarin hepsini ovaya.

Güzel sularım dolup taşlyor ölülerle,

Tanrisal denize akıtamiyorum sularımı,

Öldürdüğün insanlar tıkadı beni,

Boyuna da kesip biçiyorsun hiç acımadan.

Bikttm senden Kronosoğlu, yeter artık."(Homeros, Ill. XXI, 210-215)

Skamandros, Akhilleus'un durmayacağını anladığında, önce Troialıları koruması için Apollon'a seslenir, ancak sonunda Akhilleus'u kendisi durdurmaya karar verir.

Irmak böyle dedi, kargısı ünlü Akhilleus atladı kıyıdan ırmağın ortasına.

Irmak şahlanıp şahlanıp saldırdl,

Alt üst etti sularinı kabara kabara,

Yatağından yığııla yatan ölüleri aldı götürdü,

Firlattı kyyllardan dışarı bir boğa gibi böğürerek.

Kurtarlyordu güzel sularında kimi diri görürse,

Sakliyordu kocaman anaforlarin dibine.

Korkunç, bulanık bir dalga sardı Akhilleus'un dört yanını,

Kalkanına çarptı itti onu akintısıly.

Akhilleus böylece çıktı akıntıların içinden,

Vardı karaya uçar adımlarla, başladı koşmaya,

Derin bir korku sarmışt yüreğini.

Ama koca tanrı yakasinı bırakmadı onun,

Kapkara bir dalgayla saldırdı ona,

Kesmek istiyordu Akhilleus'un soluğunu,

Belayl savmak istiyordu Troialıların başından.

Peleusoğlu firladı, bir kargl atımlık yol aldl.

Kara kartalın hizı vardı onda, avcı kartalın,

Kuşların en ünlüsü, en hizlisı kartalın.

Kurtulmak için kaçıyordu bucak bucak.

Ama Xanthos gümbür gümbür sularlyla kovalyyordu onu.(Homeros, İl. XXI, 135-255.)

Troia savaşlarında sadece Akhalar içinde değil, tüm savaş̧̧ılar arasında en güçlü ve korkusuz olan, bu nedenle sayısız insanı öldüren Akhilleus ilk defa bu kadar korkmuş ve çaresiz durumdadır. Bu nedenle babası Zeus'a yalvararak kendisini kurtarmasını ister.

Zeus baba, yok mu tanrlar arasinda bana actyan? 
Akhilleus'un bu yalvarmalarına karşılık tanrılardan Athena ve Poseidon yardıma gelirler. Fakat Skamandros'un öfkesi dinmek bilmez öyle ki ovadaki diğer ırmak Simois'e de seslenerek birlikte Akhilleus'un Priamos'u yok etmesine engel olmasını ister. Simois ile birlikte iyice güçlenen Skamandros'un önüne Olympos tanrıları bile çıkamaz olmuştur. Bunun üzerine Hera, oğlu demirci tanrı Hephaistos'u çağırır. Akhilleus bu saldırıdan ancak Hephaistos'un yardımıyla kurtulabilmiştir (Homeros, Il. XXI, 340-385; Mackie 1998).(RESIM 3)

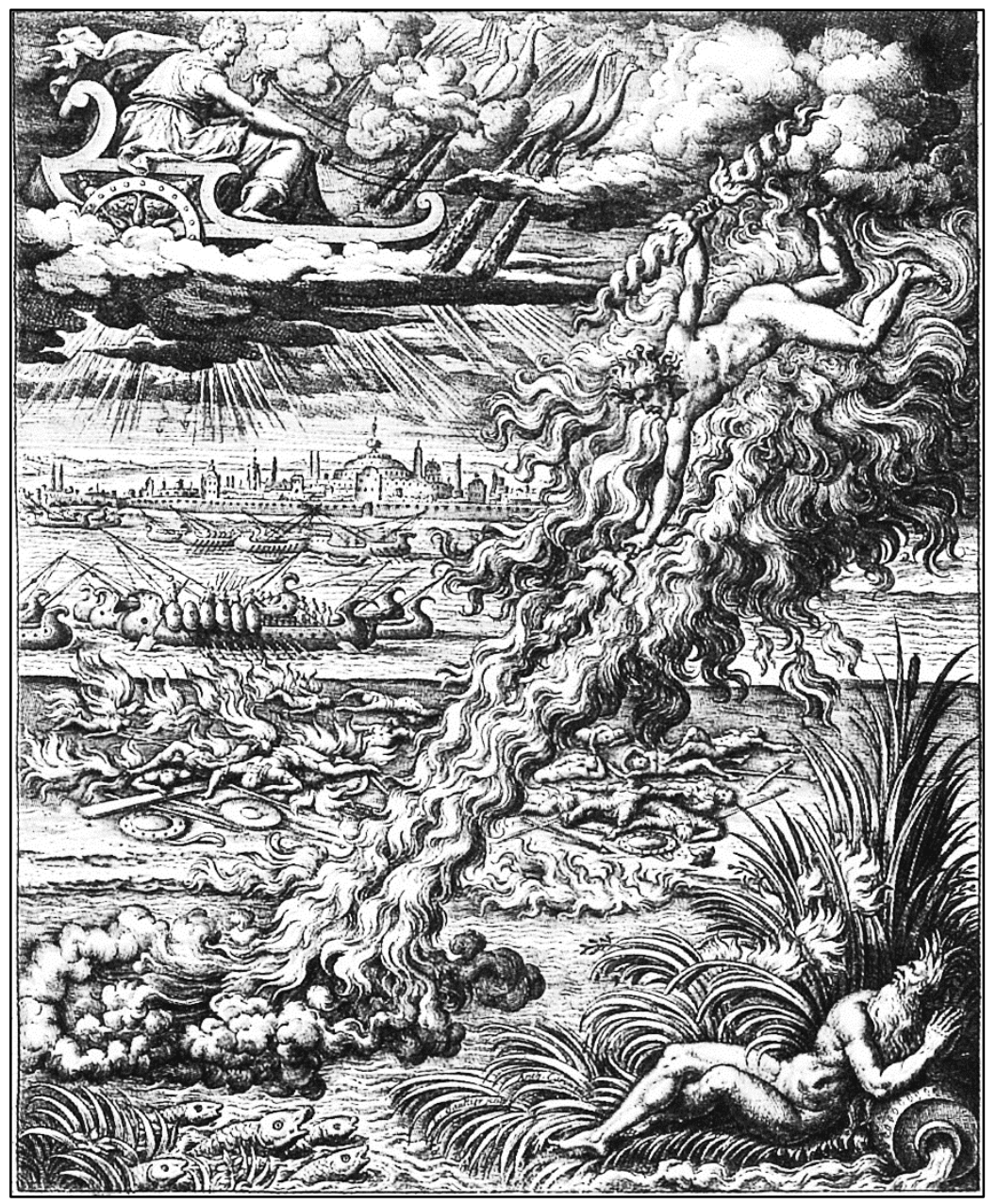

RESIM 3: Philostratus'un 1614 yılında yayınlanan kitabı içindeki gravür (Scamander' tableau)

Hephaistos, sadece Skamandros'u değil ateşiyle tüm ovayı yakar. Yangında Skamandros ve Troialılarınyanısıra ovadaki Akhaların da yok olacağını gören Hera sonunda oğlundan bu ateş firtınasını durdurmasını ister. Hephaistos yangını kesince de, Skamandros yatağına tekrar geri çekilir.

Philostratus'un eserinde de anlatmış olduğu bu olay Troia mitolojisinin ayrılmaz bir parçası olarak Roma dünyasında ve sonrasında pek çok tasviriyle karşımıza çıkmaktadır (Squire ve Elsner 2016).Troia savaşının bir bütün olarak tasvir edildiği Tabulaelliacae üzerindeki firizlerde de Skamandros'un Akhilleus'u kovaladığı sahne yer almaktadır. (RESİM 4)

Skamandros, Troia savaşlarında, savaşa karışan Olympos tanrıları arasında, tanrıların savaşında, Troas'ın tek yerel tanrısı olarak dikkat çeker. Onun Olympos tanrıları ile birlikte gösterilmesi bu nehir tanrısının bölgenin en büyük tanrısı olduğunun göstergesidir (vonHahn, et all. 1997). O da tıpkı Hektor gibi Troia'nın en önemli koruyucularından biridir.

İliada destanında Troia kahramanlarından Hektor oğlu Astynax’tan "Skamandroslu” diye söz etmektedir. Andromakhe karşıladı Hektor'u

dadı da arkasindan geliyordu,

memedekiyavrucă̆ızı taşıyordu kucă̆ında, 
Hektor'un gözbebeğiydi o,

ışıldayan yıldıza benziyordu,

HektorSkamandros'lu derdi ona,

başkalarıAstynax, şehrin krall, derdi,

İlyon'u tek başına koruyan Hektor'du da

ondan. (Homeros, Il. VI, 400)



RESIM 4: TabulaeIliacae üzerindeki firizlerde de Skamandros'un Akhilleus'u kovaladığı sahne detayı.

Troia'nın koruyucusu Skamandros, kentin düştüğü ve hanedanının yok edildiği Troia’nın son günlerinde de gene karşımıza çıkar. Akhaların savaşın sonunda kenti ele geçirmek için başvurdukları son girişim Troia kapılarına bıraktıkları tahta attır. Kentin sakinleri uzun süren savaşın da verdiği bıkkınlıkla, tahta atı kente almayı düşünürken, bazıları ise Akha'ların bu hediyesini kentin koruyucu tanrısı Skamandros'a atmayı teklif eder. Ama sonunda tahta at surların içine alınıp, kaçınılmaz kader gerçekleştiğinde, Akhalar, Troialıları kadın erkek çocuk ayırmadan katletmeye başlarlar. Akhalar özellikle erkek çocuklarını ileride babalarının intikamını almasınlar diye öldürürler. Hektor'un oğlu Astynax, Troia surlarından Skamandros'a atılmak suretiyle katledilir. Böylece, ironik bir şekilde, Troia'yı kurtaracak olan tahta atın Skamandros'a sunulması yerine, "Skamandroslu" Astynax, Skamandros'a atılmak suretiyle, Troia hanedanının son ferdi de yok edilmiştir (vonHahn, et all. 1997).

\section{Antik Çă̆ Ritüellerinde Skamandros Irmağı}

Troia mitolojisinin vazgeçilmez figürlerinden biri olan Skamandros, hem Troia kenti kurucularının atası sayılması, hem de Troia savaşları sırasında Troia'lıların koruyucusu olması nedeniyle, klasik çağlarda halkın günlük yaşantısındaki birtakım ritüeller içerisinde de yerini almıştır. Bu ritüellerin en bilineni Troialı genç kızların evlilik öncesinde Skamandros'a giderek ırmağa girmeleri ve yıkanmalarıdır. Ps. Aeschines'in, Troia'da bizzat tanık olduğunu söylediği böyle bir törende, Troia civarında evlilik çağındaki genç kızlar ailelerin gözetiminde toplu bir şekilde ırmağa doğru giderler ve her biri ırmağın uygun bir yerinde yıkanırlar. Yıkanma sırasında ırmağa dua eden genç kızlar yüksek sesle:

\section{“ $\Lambda \alpha \beta \varepsilon \mu о v \Sigma \kappa \alpha \mu \alpha \nu \delta \rho \varepsilon \tau \eta v \pi \alpha \rho \theta \varepsilon v i \alpha v "$}

"Ey Skamandros, al benim bekaretimi”

diye seslenirler (Ps.-Aesc.Epist. 10. 3-8; Trenkner 1958; Gallini 1963; Dillon 2002; Rosenmeyer 2006; Hodkinson 2013).

Yazarın sözünü ettiği bu gelenek yılın belli bir zamanında yapılan ve o sene evlenme çağına gelen genç kızların katıldığ 1 bir festivaldi. Bu festivalden dört gün sonra da kentte Aphrodite onuruna bir tören alayı düzenleniyor ve rrmakta yıkanan genç kızlar bu törende yürüyorlardı. Bu festival Atina ve Yunan dünyasının diğer yerlerinde gördüğümüz evlilik öncesi yıkanma-arınma ritüellerinden daha farklı ve sadece bu bölgeye özgü bir festivaldi. Bazı yazarların doğurganlık, evlilik öncesi bir arınma banyosu olarak gördüğü bu gelenek aslında Skamandros'un, bölge insanının günlük hayatlarındaki ritüellerine nasıl yansıdığının güzel bir örneğidir (Beaulieu 2016). 


\section{Nehir Tanrisı Skamandros'un İkonografisi}

Ps. Aeschines, yukarıda bahsetmiş olduğumuz olayın devamında, arkadaşı Kimon'un ırmakta bu şekilde yıkanan ve Skamandros'abekaretini alması için seslenen genç kızlardan birini nasıl baştan çıkardığını da anlatır. Çapkın Kimon, ırmak kıyısında bir çalılıkta gizlenir ve başını sazlarla taçlandırır. Böylece kendini tanrı Skamandros'a benzeterek zavallı kızı kandırır. Sikke ve kabartmalarında Skamandros'un başındaki çelengin sazlardan yapılmış olduğu anlaşılmaktadır. Homeros ve diğer antik metinlerde göremediğimiz bu ayrıntıyı M.S. 5. ya da 6. yüzyıla ait IliasAmbrosiana'daki minyatürler üzerinde görmekteyiz. LII numaralı minyatürde, sanatçı nehir tanrısını başında sazlardan yapılmış bir çelenk, sakallı ve omuzlarından dökülen koyu yeşil himationu ile birlikte, elinde de uzun bir saz tutar şekilde kişiselleştirdiği irmağın yanında gösterilmiştir (Bianchi ve Bandinelli 1955). (RESİM 5)Skamandros bir sunak üzerinde duran vazoya yaslanmakta, yaslandığı vazodan ise ırmağın suları akmaktadır. IliasAmbrosiana' da, LIII numaralı diğer minyatürde, hem Homeros, hem de Philostratus'un eserinde anlatılan Hephaistos'un ateşiyle Skamandros'u durdurması betimlenmiştir. (RESİM 6)Burada da Skamandros'u ilk minyatürdeki giyim kuşamı ve aynı atribüleri ile görmekteyiz (Bianchi-Bandinelli 1955). İlk minyatürde Skamandros, ayakta dururken, ikincisinde kayalık olduğu açıkça belli bir yamaca dayanmıştır. İda Dağını simgeleyen bu kayaları, Skamandros'unPompei'de bulunan başka bir tasvirinde de görürüz. Pompei'de, Casa del Criptoportico'da M.S. 1. yüzyılın ikinci yarısına tarihlenen bu duvar resminde, Akhilleus'un Lykaon'u öldürdüğü sahnedeİda Dağının yamacına oturan tanrının elindeki vazodan(?) ırmağın suları aşağıya doğru dökülmektedir (Spinazzola 1953).

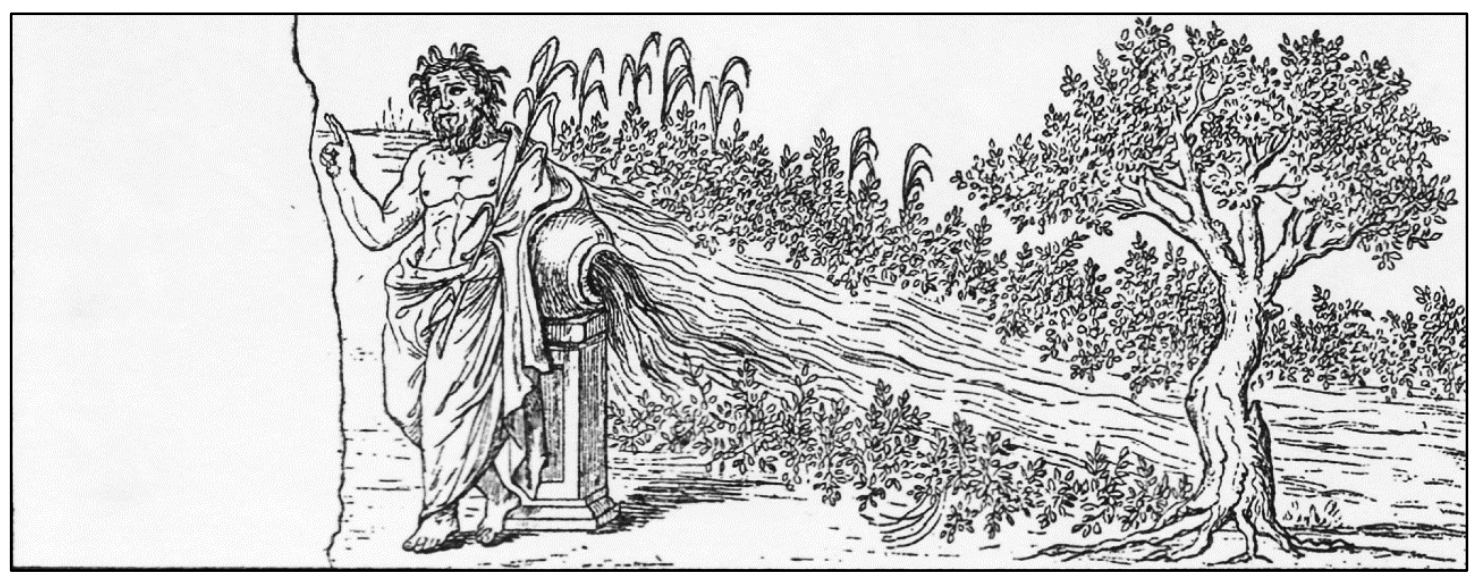

RESİM 5 IliasAmbrosiana'dakiFigure4.2, miniature L II

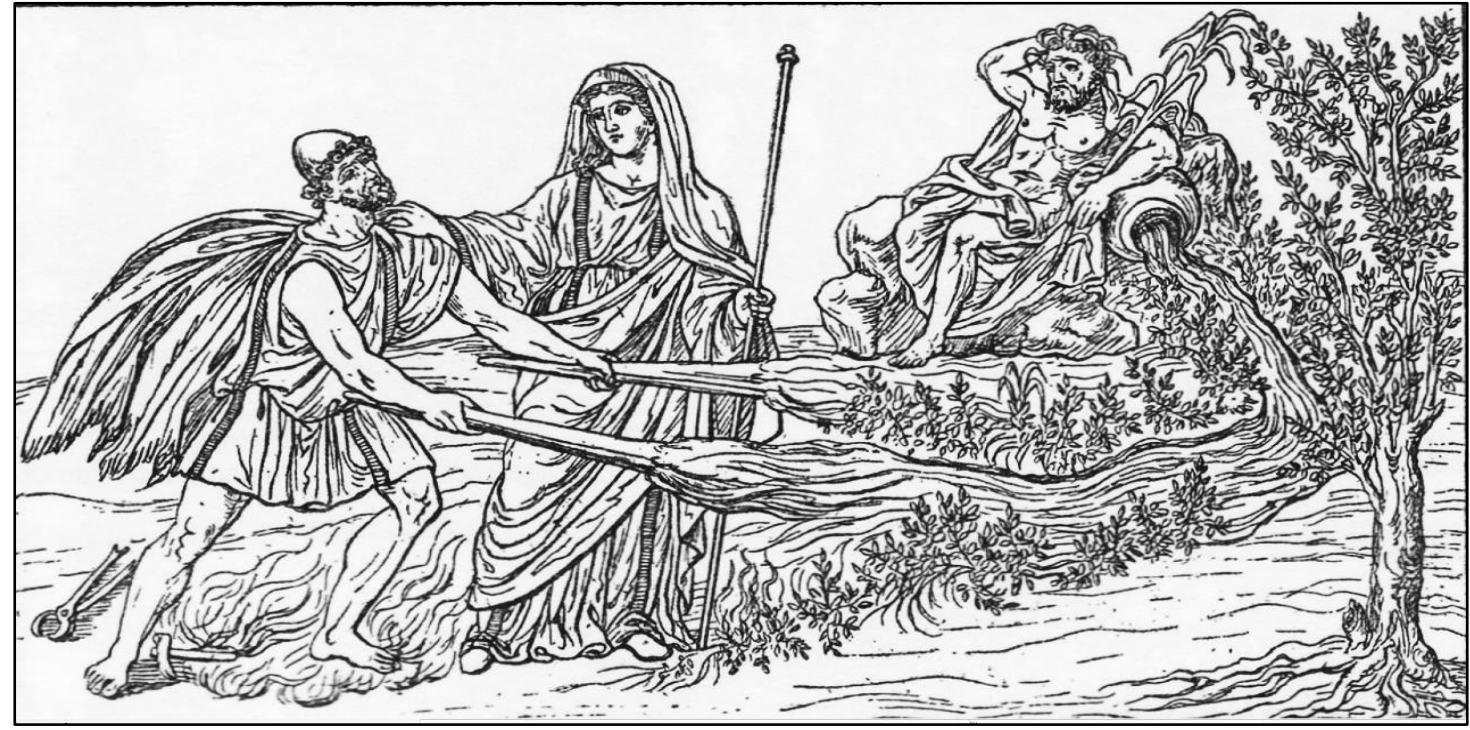

RESİM 6 IliasAmbrosiana'dakiFigure 4.3, miniature L III

Üzerinde nehir tanrısı Skamandros'un tasvirinin bulunduğu yazıt ve kabartma 1966 yılında Karamenderes'in Akçin çayı ile birleştiği yerde bulunmuştur. Çanakkale Arkeoloji müzesinde 2330 envanter numarası ile kayıtlı bulunan ve M.S. 2. yüzyıla tarihlenen bu kabartma, bir 
dikdörtgen/karesunağın bir parçasıdır. (RESİM 7) Muhtemelen ırmak kıyısında nehir tanrısı Skamandros'a ait bir kutsal alan içinde bulunmaktaydı. Stelin sol köşesinin buraya bağlanan diğer bir parçayla dikdörtgen/kare şeklini oluşturduğu anlaşılmaktadır.

Dikdörtgen şeklindeki stelin üzerinde soldan sağa doğru: Bir quadriga ve süvarisi ile onu ayakta karşılayan ayakta çıplak bir figür, ortada at üzerinde binicisi ve en sağda kline üzerinde uzanmış bir figürün önündeki sunağa libasyon yapan bir kişi yer alır. Kline üzerindeki figür başını sahnenin üzerindeki bordüre yapışmış ve sağ tarafa yaslanmıştır. Kısa saçlı ve sakalsız olan figür karşıya doğru bakmaktadır. Üzerinde vücudunun üst kısmını açıkta bırakan bir himation vardır. Sol kolu üzerine yaslanmış, sağ elinde ise yuvarlak bir nesne tutmaktadır. (RESİM 8) Altta bulunan yazıttan kline üzerine uzanan bu kişinin nehir tanrısı Skamandros olduğu anlaşılmaktadır. Sahne aslında bu tanrıya yapılan sunuyu tasvir etmektedir. Zafer Taşlıklıoğlu, yazıtı okumuş ve tercüme etmiştir (Taşlıklığlu 1971).

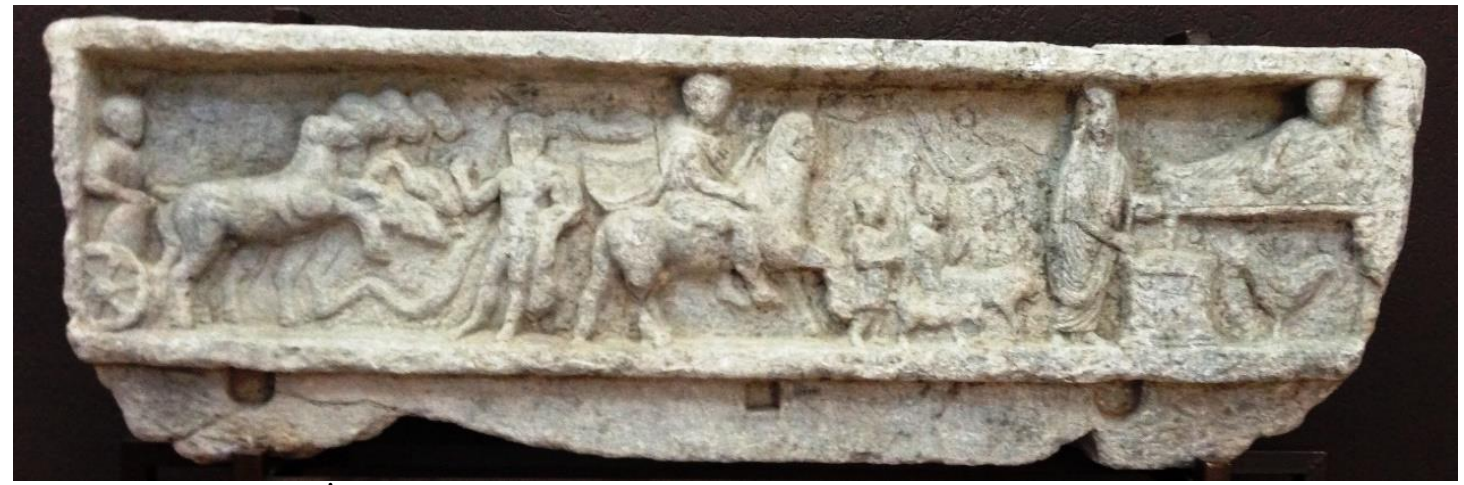

RESIM 7 Ezine yakınlarında Karamandres içinde bulunan kabartma

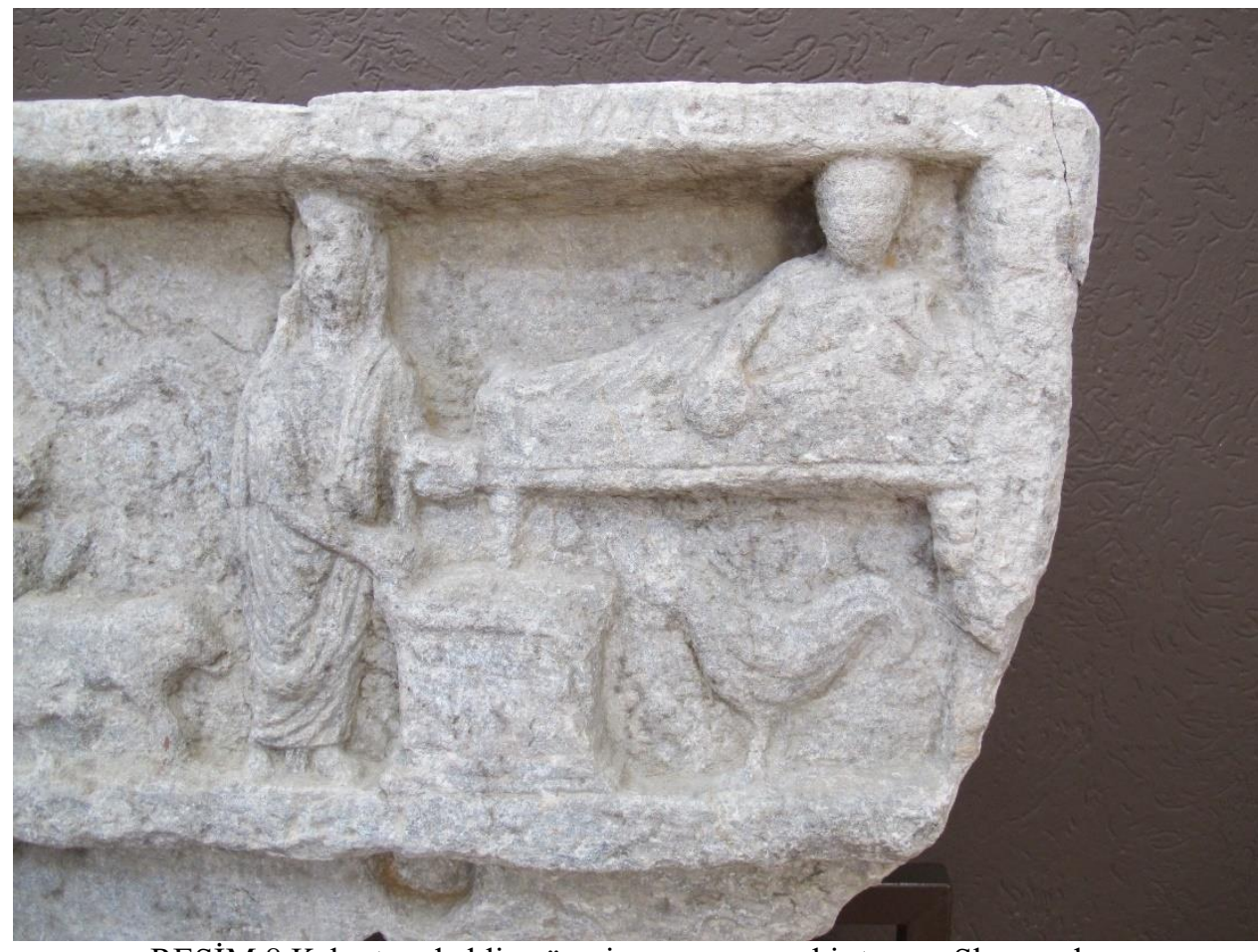

RESIM 8 Kabartmada kline üzerine uzanmış nehir tanrısı Skamandros 


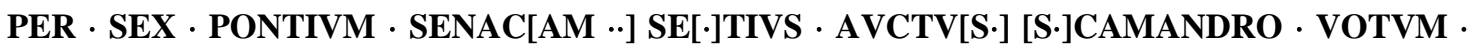
SOLVIT $\cdot$ CVRATOR[I].

"Sex. Pontius Seneca'nın yardımıyla Se[n]tiusAuctus, koruyucu [ihtimam gösteren tanrı] Skamandros'a adağını sundu."

Troasbolgesi yazıtları üzerine çalışmalar yapan Mariana Ricl ise yazıtı biraz daha farklı bir şekilde tercüme etmiştir (Ricl 1997)

\section{[..?PON]TIUS AUCTUS [S]CAMANDRO VOTUM SOLVIT CURATOR E(FFECIT) PER SEX(TUM) PONTIUM SENECAM}

\section{“ PontiusAuctus yeminini bozduğu için SextusPontius Seneca'nın gözetiminde Skamandros'a} sundu."

Nehir tanrısı Skamandros'a ait bir başka heykel İstanbul Arkeoloji Müzelerinde bulunmaktadır (Pasinli 1992). Burada Skamandros sağa doğru yaslanmış pozisyonda ve sağ kolunun altında irmağın sularının aktı̆̆ bir amphora bulunur. Ayrıca sağ elinde bir bereket boynuzu tutmaktadır (Altınoluk 2005). Troia'dan getirilmiş olan bu heykelin tarihi de M.S. 2. yüzyıldır. Troia'da muhtemelen bir çeşme yapısını süsleyen bu heykelin Skamandros kültüyle ilişkili olduğunu söyleyebiliriz.

Gene İstanbul Arkeoloji Müzelerinde bulunan ve Troia'dan gelmiş olan bir başka kabartma üzerindeki ırmak tanrısı betimlemesinin Skamandros veya Simois olduğu düşünülmektedir (Altınoluk 2005).

Skamandros heykel ve kabartmalar dışında Roma çağında başta Troia olmak üzere Skepsis ve Kyme sikkeleri üzerinde de karşımıza çıkar (Mionnet 1808; Imhoof-Blumer 1924; Bellinger 1961; Tekin, Altınoluk ve Körpe 2009). (RESIM 9) (RESIM 10) Kabartmalarda pek çok nehir tanrısı gibi orta yaşlı sakallı bir erkek olarak tasvir edilen Skamandros, aynı şekilde Roma İmparatorluk dönemi sikkeleri üzerinde de daima sırtını bir yere dayanarak uzanır vaziyette betimlenmiştir (Altınoluk 2005). Kolunun altında içinden ırmağın kaynağının çıktığı yatay vaziyette bir amphora veya benzeri bir kap bulunur. Skamandros'u diğer nehir tanrılarından ayıran özelliği ise elinde tuttuğu bitki sapıdır. Hem Kyme sikkelerinde, hem de İlion sikkesinde tanrı elinde uzun saplı bir dal tutmaktadır. İlion sikkesinde belli olmasa da, Kyme sikkelerinde bu sapın ucunda geniş yapraklar bulunur. Skamandros ırmağında yetişen bir tür su bitkisi olduğu düşünülen bu bitkilerin günümüzde halen Karamenderes kıyılarında yetişmektedir.

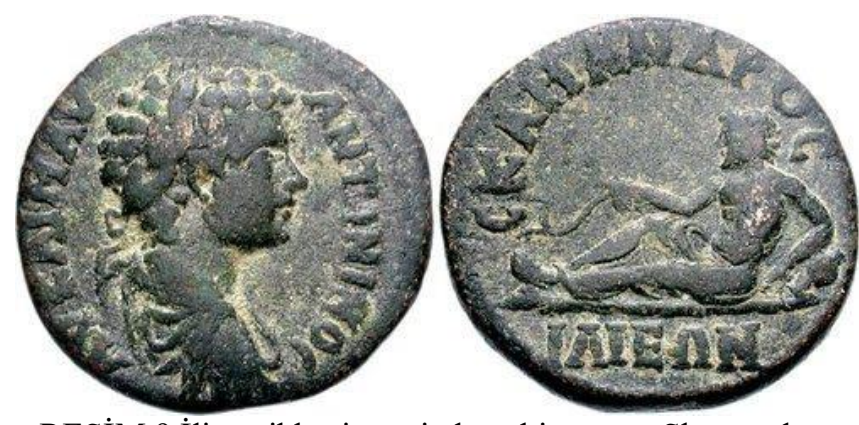

RESIMM 9 İlion sikkesi üzerinde nehir tanrısı Skamandros
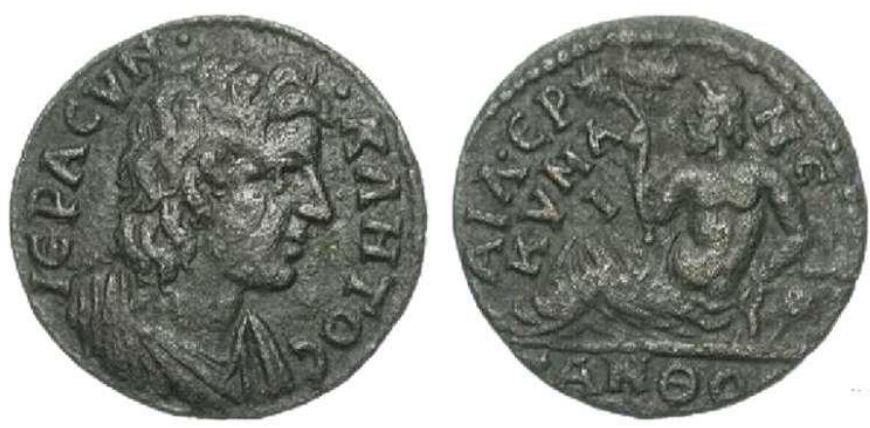

RESIM 10 Kyme sikkesi üzerinde nehir tanrısı Skamandros 
Antik çağlarda bebeklere yerel nehir adlarının verilmesi oldukça sık yaşanan bir durumdur (Larson 2007). Skamandros, bu nedenle Troas bölgesinde erkek ismi olarak yaygın bir şekilde karşımıza çıkar. Çanakkale Boğazı kıyısındaki Dardanos kenti yakınlarında bulunan Dardanos Tümülüs'ünün, mezar odasının girişinde bulunan kitabede yazan Skamandros ismi ile Troia'da bir yazıtta geçen Skamandros isimleri, böyle bir geleneğin Troas’ta da yaygın olduğunu gösterir (Duyuran 1960; Frisch 1975; Clarke 1809).

\section{Sonuç}

Günümüzde Troas bölgesinin önde gelen akarsularından biri olan Skamandros aynı zamanda Troia mitolojisinin de en bilinen karakterlerinden biridir. Homeros destanlarında hem bir nehir, hem de nehrin tanrılaştırılmış haliyle karşımıza çıkan Skamandros, Homeros tarafından Troialıların en yakın müttefiki olarak tasvir edilir.

Antik çağlar boyunca Troia yakınından akıp giden bu ırmak hem bir akarsu olarak, hem de nehir tanrısı olarak Troialıların dini ritüellerinde Roma döneminin sonuna kadar kendine yer bulmaya devam etmiştir. Skamandros'ın ırmağa yakın bir yerde kutsal alanı bulunduğu gibi, Troia ve bazı kentlerde basılan Roma dönemi sikkelerinde nehir tanrısı olarak betimlenmiştir. Irmak Geç Tunç Çağından, Hıristiyanlığın kabul edildiği Geç Antik Çağa kadar bölgede yaşayan insanlar arasında saygı görmüştür. Böylece Skamandros, Troas bölgesindeki Geç Tunç Çağı kültlerinin daha sonraki yüzyıllarda da devam ettiğini gösteren önemli bir örnektir.

\section{Kaynakça}

Altınoluk, S. C (2005). "Sikkelerin Işığında Küçük Asya'da Irmak Tanrıları ",Yayınlanmamış Doktora Tezi, İstanbul Üniversitesi.

Beaulieu, M. C (2016). The Sea in the GreekImagination, Philadelphia.

Bellinger, A. R (1961). Troy: The Coins. TroyExcavationsSupplementaryMonograph I. Princeton.

Bianchi-Bandinelli, R (1955). HellenisticByzantineMiniatures of the Iliad, Milan.

Clarke, E. D (1809). Greek Marbles, Cambridge.

Dillon,M (2002). Girls And Women in ClassicalGreekReligion, New York.

Duyuran, R (1960). “Decouverted'untumuluspres de l'ancienne Dardanos”, Anadolu/Anatolia, 5, 912.

Erhat, A (2015). Mitoloji Sözlüğü, İstanbul.

Frisch, P (1975). DieInschriftenvonIlion, InschriftenGriechischerStddteausKleinasiens, III Bonn.

Gallini, C (1963). 1963. “Katapontismos.” SMSR 34: 61-90.

Hodkinson, O (2013). "Epistolarity and Narrative in Ps.-AeschinesEpistle10", EpistolaryNarratives in Ancient GreekLiterature, Edit. OwenHodkinson, Patricia A. Rosenmeyer, EvelienBracke, Boston, 323-348.

Imhoof-Blumer, F (1924). Flus-undMeergötteraufgriechichenundrömischenMünzen, Genf.

Korfmann, M (2004). "HolzfürTroia - ZurFlößereiauf dem Skamandros/Xanthos", Anadolu'da Doğdu - 60. Yaşında Fahri Işık'a Armağan / Festschriftfür Fahri Isik zum 60. Geburtstag, İstanbul, 427-438.

Körpe, R. ve Yavuz, M. F (2007). “Antik Çağlarda Troas’da Ağaç ve Ağaç Taşımacılığıı”, Bayramiç Sempozyumu 2007, 03-05 Ağustos 2007, Bayramiç, 19-22. 
Körpe, R (2017). "Antik Çağda Troas Bölgesi Yol Sistemi", II. Uluslararası Anadolu Uygarlıkları Sempozyumu (Yollar-Köprüler), Çorum, Türkiye, 27-28 Nisan 2017, 1-40.

Larson, J (2007). Ancient GreekCults, London.

Mackie, C. J (1998). “Achilles in Fire”, The ClassicalQuarterly, Vol. 48, No. 2 (1998), 329-338.

Mionnet T. E (1808). Description de medaillesantiques, grecques et romaines, vol. 3, Paris.

Pasinli, A (1992). “ArchaologischesMuseum İstanbul”, AntW 23, 1992, 30-31.

Ricl, M (1997). The Inscriptions of AlexandreiaTroas, Bonn.

Rosenmeyer, P. A (2006). Ancient GreekLiteraryLetters, New York.

Spinazzola, V (1953). Pompei alla lucedegliscavinuovidiViadell'Abbondanza (anni 1910-1923). 3 vols. Roma.

Squire - Elsner, $\quad$ Squire M. ve Elsner, J (2016). "Homer and the Ekphrasists: Text and Picture in the ElderPhilostratus' 'Scamander' (ImaginesI.1)", The Archaeology of Greece and Rome StudiesInHonour of Anthony Snodgrass, Edit. John Bintliff ve N. KeithRutter, Edinburgh University Press.

Taşlıklığlu, Z (1971). Trakya’da Epigrafi Araştırmaları, İstanbul.

Tekin, O, Altınoluk, S. C. ve Körpe, F (2009). SyllogeNummarumGraecorum Turkey 3, Çanakkale Museum, İstanbul.

Trenkner, S (1958). The GreekNovella in the ClassicalPeriod, Cambridge.

vonHahn, J. G. - Finlay, G. - David, A. Traill, “J. G (1997). vonHahn's Report of His Excavations at Balli Dağ in 1864: The FinlayTranslation", The Annual of the British School at Athens, Vol. 92, 169-189. 